\title{
ע Nuorten aikuisten syrjäytymiseen liittyvät tekijät ja sosiaali- ja terveyspalveluiden ajoittuminen
}

Päätöksenteossa ei tunnisteta rïttävän hyvin syräytymisen taustalla olevia syitä ja olosuhteita. Tämä johtaa pistemäisiin ratkaisuihin ja usein ihmisten pallotteluun ja ongelmien monimutkaistumiseen. Tarjottavat palvelut ja todelliset tarpeet eivät myöskään välttämättä kohtaa.

Tässä tutkimuksessa kouluttamattomuutta 25 -vuotiaana ja pitkittynyttä työttömyyttä 25-28-vuotiaana tarkastellaan syrjäytymisenä, jolloin tietyt elämänkaarelle normaalisti kuuluvat asiat ovat jääneet saavuttamatta.

Tässä tutkimuksessa selvitettiin Kansallinen syntymäkohortti 1987 -rekisteriaineiston avulla ( $N=60$ 069), kuinka suurta osuutta ikäluokasta syrjäytyminen koskee aikuisuudessa, sekä miten syrjäytyminen jakaantuu sukupuolittain. Tutkimuksessa selvitettiin myös, mitkä tekijät lapsuudessa ja nuoruudessa liittyvät syrjäytymiseen, sekä näiden tekijöiden yleisyyttä koulutettujen työllisten, koulutettujen työttömien, kouluttamattomien työllisten sekä syrjäytyneiden ryhmien välillä. Tutkimuksessa tarkasteltiin myös lapsuuden ja nuoruuden sosiaali- ja terveyspalveluiden käyntimäärïä ja ajoittumista koulutettujen työllisten ja syrjäytyneiden ryhmissä.

Ikäluokasta 3,7 prosenttia eli 2186 henkilöä voitïn kouluttamattomuuden ja pitkäaikaisen työttömyyden vuoksi lukea kuuluvan syrjäytyneiden ryhmään 25-28-vuotiaana. Enemmistö heistä oli miehiä. Kouluttamattomuus oli pitkäaikaista työttömyyttä vahvemmin yhteydessä muihin ongelmiin, ja syrjäytyneillä voitiin nähdä jo lapsuudessa ja nuoruudessa useita muita omia ja perheeseen liittyviä ongelmia. Syrjäytymiseen liittyvissä tekijöissä voitiin nähdä eroja sukupuolen mukaan. Huomattavaa oli, että syrjäytyneiden ryhmän sosiaali- ja terveyspalveluiden käyttö ja ajoitus erosivat merkitsevästi koulutettujen työllisten ryhmän palveluiden käytöstä.

Tämän tutkimuksen tulokset vahvistavat, että koulutus ja työelämään kiinnittyminen kietoutuvat voimakkaasti toisiinsa ja myös aiemman elämän hyvinvointiongelmat ovat näihin voimistuen yhteydessä. Tutkimus täydentää aiempaa tietoa syrjäytymiseen liittyvistä tekijöistä ja sukupuolittuneisuudesta. Tutkimus tuo myös lisätietoa palvelujärjestelmän suhteesta syrjäytymiseen.

ASIASANAT: nuoret, sosiaali- ja terveyspalvelut, hyvinvointi, syrjäytyminen, NEET

REIJA PAANANEN, ANNE SURAKKA, SAKARI KAINULAINEN, TIINA RISTIKARI, MIKA GISSLER 


\section{YDINASIAT}

- Päätöksenteossa ei tunnisteta riittävän hyvin syrjäytymisen taustalla olevia syitä ja olosuhteita.

- Tutkimus osoitti, että nuoret miehet ovat nuoria naisia suuremmassa syrjäytymisvaarassa.

- Syrjäytyneet tulivat sijoitetuksi kodin ulkopuolelle sekä psykiatriseen osastohoitoon ja päihdehoitoon koulutettuja työllisiä myöhemmin.

- Syrjäytymisen syynä voi olla mielenterveys- ja päihdeongelmien lisäksi niihin saadun avun riittämättömyys tai avun saaminen liian myöhään.

\section{JOHDANTO}

Yksi keskeinen yhteiskunnallinen haaste on, miten ja millaisen kehityskulun kautta nuoret ikäluokat siirtyvät koulutukseen ja työelämään ja miten heitä voitaisiin tukea. On tärkeää löytää ratkaisuja, joiden avulla kukaan ei jäisi koulutuksen ja työmarkkinoiden ulkopuolelle, sillä alhainen koulutus ja työelämän ulkopuolisuus heikentää työmarkkinamahdollisuuksia ja luottamusta yhteiskuntaan myös myöhemmin (1). Koulutuksen ja työelämän ulkopuolisuus on yhteydessä myös muihin ongelmiin, kuten mielenterveyden ja talouden ongelmiin (2) ja etenkin pitkittyessään työttömyys lisää ongelmien sekä työttömyyden todennäköisyyttä myöhemminkin (3-5). Nuorilla työttömyyden haavoittava vaikutus on poikkeuksellisen vakava, koska se voi olla pitkäaikaista ja kestää mahdollisesti koko työuran (4).

Suomessa erityisesti nuorten, 20-24 -vuotiaiden miesten koulutuksen ja työelämän ulkopuolisuus (NEET - not in employment, education or training) on lisääntynyt viime vuosikymmenen aikana, mitä selitetään yleisellä nuorisotyöttömyyden kasvulla ja työmarkkinoiden muutoksella siten, että koulutus on nykytyöelämän vaatimuksiin riittämätöntä (6). Selkeää syytä ei kuitenkaan ole löytynyt, miksi Suomessa nuoria miehiä tilastoidaan NEET-nuoriksi naisia useammin. Suomessa 11 prosenttia 15-24-vuotiaista tilastoitiin NEET-nuoriksi vuonna 2015 (7), mikä on hiukan alle EU:n keskitason, mutta pohjoismaisesti korkea. Suomessa NEET-nuorista kuudesosa (16\%) luokitellaan sairauden tai vamman vuoksi ulkopuoliseksi. EU:n keskiarvoon $(7 \%)$ nähden osuus on yli kaksinkertainen (7). Koulutuksen ja työelämän ulkopuolella olevien nuorten ryhmä on kuitenkin hyvin hetero- geeninen, ja EU suositteleekin, että kunkin maan toimenpiteet olisi räätälöitävä perustuen tietoon tarkemmista NEET-alaryhmistä.

Vaikka NEET-status onkin yleinen nuoruuteen liittyvä välivaihe (2), pitkittynyt kouluttamattomuus ja työttömyys ovat keskeinen osa syrjäytymistä, joka itsessään on laveampi ilmiö ja vailla selkeää määritelmää (8). Nuorista puhuttaessa syrjäytyminen määritellään usein ulkopuolisuudeksi hyvinvointivaltiolle kuuluvista integraatiotehtävistä, kuten koulutuksesta ja työelämästä; kasvatustieteen näkökulmasta taas syrjäytymisenä ns. normaalina pidettävästä kasvusta ja kehityksestä (9). Joka tapauksessa syrjäytyminen on ongelmavyyhti, jossa ongelmat kasautuvat ja pitkittyvät (8). Syrjäytymisen riskien tiedetään liittyvän kiinteästi nuoren aikaisempaan elämään. Lapsuuden perheen taloudelliset ja terveydelliset vaikeudet sekä vanhempien vähäinen koulutus lisäävät nuoren kouluttamattomuutta, rikollisuutta, mielenterveyspalveluiden sekä toimeentulotuen käyttöä (10). Samoin vanhempien vaikeudet lisäävät heidän lastensa NEET-vuosien määrä: mitä enemmän NEET-vuosia nuorella on, sitä useammin taustalla nähdään vanhempien toimeentulotuen saantia, perhesuhteiden muutoksia, lyhyt koulutus tai alhainen sosioekonominen asema (2). Myös vanhempien yksinäisyys ja vuorovaikutussuhteet heijastuvat heidän lastensa koulunkäyntiin ja sosiaaliseen kyvykkyyteen, jotka ovat oleellisia myöhemmän pärjäämisen kannalta (11). Vanhempien kouluttamattomuus, työttömyys ja toimeentulotuen saanti nuoren teini-iässä ennustavat myös nuoren työttömyyttä, kouluttamattomuutta ja toimeentulotuen saantia nuoressa aikuisuudessa (12). Edellä mainittujen tekijöiden kasaantumisella tiedetään olevan voimakkaimmat ylisukupolviset vaikutukset (12).

Tiedetään, että esimerkiksi nuoren oma lastensuojelutausta (13), koulutuksen keskeyttäminen (5), maahanmuuttajuus (14), mielenterveysja päihdeongelmat (15) sekä yksinäisyys (16) ja koulukiusaaminen (17) löytyvät hyvin usein syrjäytymisen taustalta. Yhtä tai muutamaa selvää riskitekijää on kuitenkin mahdotonta osoittaa, koska ryhmä on hyvin heterogeeninen ja tutkimuksissa tunnistetut riskitekijät ovat aina yhteydessä kunkin tutkimusaineiston käytettävissä oleviin muuttujiin. Jotta nuorten syrjäytymiseen voidaan löytää ratkaisuja, pitää tietää mahdolli- 
simman kattavasti syrjäytymisen taustalla olevat tekijät ja mekanismit, sekä miten niihin voidaan vaikuttaa.

Elämänkaarinäkökulman mukaan suomalaisen nuoren ideaali elämänkaari alkaa kodin suojissa vietetystä varhaislapsuudesta. Perheen olosuhteet muokkaavat tuolloin vuorovaikutusta ja turvallisuuden tunnetta ja antavat pohjan lapsen tasapainoiselle kehitykselle. Varhaiskasvatus tai kerhotoiminta laajentaa lapsen elinpiiriä ja sosiaalisia suhteita. Tuolloin opitaan toimimaan ryhmässä, luodaan pohjaa muulle oppimiselle ja peilataan omaa olemista, osaamista ja tekemistä suhteessa muihin. Peruskoulun aikana sosiaalinen piiri laajenee. Sosiaalisten suhteiden ja joukkoon kuulumisen merkitys korostuu. Oma osaaminen, valmiudet ja itseluottamus sekä itsetuntemus vahvistuvat. Nuoruusikä on siirtymäaikaa lapsuudesta aikuisuuteen. Peruskoulun jälkeen nuoren oletetaan valintojensa kautta vähitellen löytävän oman paikkansa yhteiskunnassa. Nuoreen aikuisuuteen ajatellaan perinteisesti kuuluvan vastuu omasta elämästä, taloudellinen itsenäisyys ja koulutuksen hankkiminen, parisuhteen muodostaminen sekä työelämään siirtyminen. Näistä aikuisuuden kehitystehtävistä selviytyminen vaatii monenlaisen taitojen ja sosiaalisten suhteiden sekä persoonallisuuden kehitystä. Tähän tarvitaan myös yhteiskunnan tukea. (18-21).

Sen (22) korostaa pystyvyyden puutetta tärkeimpänä syrjäytymisen prosessissa. Hänen mielestään syrjäytyneiltä on elämänkaarella evätty pääsy pystyvyyttä tuottaviin materiaalisiin, kulttuurisiin tai tunnetason voimavaroihin. Eli käytännössä syrjäytyminen voi siis olla sitä, että on joutunut erilaisten syrjäyttävien mekanismien kohteeksi, eikä ole voinut saada aikuisuudelta vaadittavia taitoja (20). Vaadittavien taitojen saavuttaminen tai saavuttamatta jättäminen riippuu materiaalisista tekijöistä, kuten asuinpaikasta tai taloudellisesta tilanteesta; perheeseen liittyvistä tekijöistä, kuten vanhempien koulutuksesta ja tuesta, erilaisista lasten ja nuorten elämää ympäröivistä palveluista sekä yksilöön liittyvistä tekijöistä, esimerkiksi sukupuolesta. Ajatellaan, että erityisesti työllistymiseen liittyvät kyvyt ovat keskeisiä miesten identiteetille (23).

Syrjäytymiseen liittyy siis myös ulkopuolisia rakenteita, palvelujärjestelmän prosesseja sekä erilaisia tukimuotoja. Syntymän jälkeen lapsi on palveluiden ja palvelujärjestelmän, kuten sosiaali- ja terveyspalveluiden, koulutus- ja nuorisopalveluiden myönteisen ja kielteisen toiminnan ja näkökulman kohteena, mikä muokkaa lapsen ja nuoren pystyvyyttä (23). Syrjäytyneillä nuorilla on paljon kokemusta erilaisista pitkä- ja lyhytaikaisista asiakkuuksista, tukimuodoista ja viranomaisten väliintuloista jo lapsuudessa ja nuoruudessa (24). Näiden nuorten kokemukset avun ja tuen oikea-aikaisuudesta, riittävyydestä, mielekkyydestä ja toimivuudesta vaihtelevat kuitenkin paljon (24). Syrjäytyneiden nuorten tiedetään olevan vertailuryhmiä sairaampia ja käyttävän myös enemmän terveydenhuollon palveluita ja lääkkeitä (24). Tiedetään myös, että mielenterveysongelmissa nuoret miehet alikäyttävät terveydenhuollon palveluita (25), ja asuinpaikka määrittelee palvelun käyttöä siten, että mielenterveyspalvelut ovat helpommin saatavilla niille, jotka asuvat lähempänä psykiatrista osaamista (26). Näin ollen heikot palvelujärjestelmän resurssit tai saavutettavuus voivat osaltaan edesauttaa syrjäytymistä. Palveluiden merkityksestä syrjäytymisessä ei kuitenkaan vielä tiedetä kovinkaan paljon.

Tässä tutkimuksessa kouluttamattomuutta 25-vuotiaana ja pitkittynyttä työttömyyttä 2528-vuotiaana tarkastellaan syrjäytymisenä, jolloin tietyt elämänkaarelle normaalisti kuuluvat asiat ovat jääneet saavuttamatta.

Tämän tutkimuksen tarkoituksena oli selvittää:

1. Kuinka suurta osuutta ikäluokasta kouluttamattomuus 25-vuotiaana sekä pitkäaikainen, yli 300 päivän työttömyys 25-28-vuotiaana koskettaa sekä miten näin määritelty syrjäytyminen jakaantuu sukupuolittain?

2. Mitkä tekijät lapsuudessa ja nuoruudessa liittyvät syrjäytymiseen? Eroaako näiden tekijöiden yleisyys koulutettujen työllisten, koulutettujen työttömien, kouluttamattomien työllisten sekä syrjäytyneiden ryhmien välillä? Entä eroavatko tekijät sukupuolten välillä?

3. Voidaanko lapsuuden ja nuoruuden sosiaalija terveyspalveluiden käyntimäärissä tai ajoittumisessa havaita eroja koulutettujen työllisten ja syrjäytyneiden välillä? Toisin sanoen, voidaanko ajatella, että sosiaali- ja terveyspalvelujärjestelmän toiminta liittyisi syrjäytymisprosessiin. 
Tutkimus täydentää aiempaa tietoa syrjäytymisen taustatekijöistä ja sukupuolittuneisuudesta. Tutkimus tuo myös lisätietoa palvelujärjestelmän suhteesta syrjäytymiseen.

\section{AINEISTO}

Tämän tutkimuksen aineisto on Kansallinen syntymäkohortti 1987 (27). Kohortissa on seurattu kaikkia 60069 Suomessa 1987 syntyneitä lapsia raskauden alusta 31.12.2012 saakka, osin 2015 saakka. Tämän tutkimuksen aineistoon on otettu mukaan ne 1987 Suomessa syntyneet, jotka olivat elossa ja asuivat Suomessa 31.12.2015 ( $\mathrm{N}=58$ 832). Aineiston tiedot perustuvat THL:n, Tilastokeskuksen, Kelan, Väestörekisterikeskuksen, Eläketurvakeskuksen ja Oikeusrekisterikeskuksen rekisteritietoihin. Kaikilta viranomaisilta anottiin tarvittavat luvat eri rekisterien tutkimuskäyttöön. Eri rekisterit yhdistettiin henkilötunnuksin, jotka poistettiin lopullisesta tutkimusaineistosta.

Syrjäytymistä kuvaaviksi muuttujiksi valittiin jatkotutkinnon puuttuminen 25-vuotiaana sekä pitkäaikainen työttömyys (300 päivää tai enemmän) neljän vuoden aikajaksolla 25-28 -vuotiaana. Syrjäytymistä kuvataan usein koulutuksen ja työelämän ulkopuolisuudella, mutta usein käytetyt muuttujat eivät kerro pitkittyneestä huono-osaisuudesta ja todellisesta ulkopuolisuudesta, syrjäytymisestä. Esimerkiksi NEET-indikaattori kuvaa hyvin heterogeenistä ryhmää ja kertoo tilanteen vain yhdessä aikapisteessä. NEETiksi lukeutuvat esimerkiksi hoitovapaalla olevat. Tiedetään myös, että nuorten tilanteet vaihtelevat paljon ja opiskelu ja työmarkkinaaseman vakiintuminen vievät vuosia, jolloin koulutuksessa olevien sekä ulkopuolisten ja työttömien ryhmissä tapahtuu jatkuvaa vaihtelua 20 ikävuoden tienoilla. Tässä tutkimuksessa valittiin vuosi 2012 aikapisteeksi toisen asteen tutkinnon saavuttamiselle. Tuona vuonna 1987 syntyneiden ikäluokka täytti 25 vuotta. Pitkittyneelle työttömyydelle valittiin seurantajaksoksi vuodet 2012-2015, jolloin laissa määritelty nuoruus lähestyy loppuaan ja elämäntilanne yleisesti vakiintuu. Valittu syrjäytymistä kuvaava summamuuttuja kertoo todellisesta tilanteen pitkittymisestä, ja todennäköisesti myös pysyvyydestä. Tiedetään, että niistä ulkopuolisista ja työttömistä, jotka eivät ole saavuttaneet peruskoulun jälkeistä jatkotutkintoa tai jotka eivät ole opiskelemas- sa 25 -vuotiaana, $90 \%$ jää vaille jatkokoulutusta. Pitkittynyt työttömyys nuorena lisää myös myöhempää ulkopuolisuuden todennäköisyyttä (5).

Muuttujien tarkempi kuvaus:

Kouluttamattomuus kuvaa tilannetta, jossa henkilöllä ei ole peruskoulun jälkeistä toisen asteen jatkotutkintoa vuonna 2012 (25-vuotiaana). Tieto kerättiin Tilastokeskuksen koulutusrekisteristä. Jatkotutkinto puuttui 13 prosentilta 25 -vuotiaana 15 prosentilta miehistä ja 11 prosentilta naisista.

Pitkäaikainen työttömyys kertoo, oliko henkilö saanut jotain työttömyysetuutta yhteensä 300 päivää tai enemmän vuosina 2012-2015 (25-28-vuotiaana). Tieto kerättiin Eläketurvakeskuksen Ansaintarekisteristä. Huomioitavaa on, että ansaintarekisterin tiedot eivät mittaa työttömyyspäiviä vaan jaksoja, jona henkilö on saanut jotain työttömyysetuutta. Tästä jäävät siis ulkopuolelle nuoret, jotka eivät ole saaneet tällä ajalla työttömyysetuutta, vaan ovat olleet ns. tulottomia ja esimerkiksi toimeentulotuen ja asumistuen varassa. Pitkäaikaista, yli 300 päivää kestänyttä työttömyyttä oli kaikkiaan 13 prosentilla ikäluokasta 25-28-vuotiaana, miehistä 15 prosentilla ja naisista 11 prosentilla.

Analyysejä varten ikäluokka jaettiin sukupuolittain ryhmiin koulutuksen ja pitkittyneen työttömyyden suhteen seuraavasti:

1. Koulutetut työlliset: Jatkotutkinto 25-vuotiaana, ei pitkäaikaista työttömyyttä 25-28-vuotiaana.

2. Koulutetut työttömät: Jatkotutkinto 25-vuotiaana, pitkäaikainen työttömyys 25-28-vuotiaana.

3. Kouluttamattomat työlliset: Ei jatkotutkintoa 25-vuotiaana, ei pitkäaikaista työttömyyttä 25-28-vuotiaana.

4. Syrjäytyneet: Ei jatkotutkintoa 25-vuotiaana, pitkäaikainen työttömyys 25-28-vuotiaana.

Syrjäytymiseen liittyvinä muuttujina tarkasteltiin aiempien tutkimusten perusteella elämänkaarinäkökulmasta merkityksellisiä Kansallinen syntymäkohortti 1987 -aineistosta löytyviä tietoja $(8,10,28)$, joiden yleisyys väestötasolla on huomattava. Muuttujina tarkasteltiin seuraavia:

Toimeentulotuen saanti kertoo, oliko henkilö saanut toimeentulotukea vuosina 2002-2012 eli 15-25-vuotiaana. Tieto kerättiin THL:n Toimeentulotukirekisteristä. Vuonna 1987 syntynei- 
den ikäluokasta 25 ikävuoteen mennessä toimeentulotukea oli saanut kaikkiaan 30 prosenttia.

Pitkäaikainen toimeentulotuen saanti kertoo, oliko henkilö saanut 20 kuukautta tai enemmän toimeentulotukea vuosina 2011-2012 eli 24-25-vuotiaana. Ikäluokasta pitkäaikaisesti toimeentulotukea oli saanut 2 prosenttia. Pitkäaikainen toimeentulotuen saanti sisältyy edellä kuvattuun laajempaan muuttujaan Toimeentulotuen saanti.

Psykiatrinen diagnoosi -tieto kertoo, oliko henkilö saanut julkisesta erikoissairaanhoidosta psykiatrisen diagnoosin ICD-9 (290-319), ICD10 (F00-99) vuosina 1987-2012 eli 0-25-vuotiaana. Tieto kerättiin THL:n Hoitoilmoitusrekisteristä. Psykiatrinen diagnoosi oli asetettu 17 prosentille ikäluokasta.

Päihdediagnoosi -tieto kertoo, oliko henkilö saanut julkisessa erikoissairaanhoidossa päihteisiin liittyvän diagnoosin (ICD-10: F10-F19) vuosina 1996-2012 eli 9-25-vuotiaana. Päihteisiin liittyvä diagnoosi oli asetettu 3 prosentille ikäluokasta. Päihdediagnoosit sisältyvät edellä kuvattuun laajempaan muuttujaan Psykiatrinen diagnoosi.

Rikostuomio -tieto kertoo, oliko henkilö saanut oikeuslaitoksen tuomion rikoksesta tai rikoksista vuosina 2002-2012 eli 15-25-vuotiaana. Tieto saatiin Oikeusrekisterikeskuksen tuomioistuinlaitoksen rekisteristä. Rikostuomion oli saanut 11 prosenttia ikäluokasta.

Kodin ulkopuolelle sijoitus kertoo, oliko henkilö ollut lastensuojelun tukitoimenpiteenä kodin ulkopuolelle sijoitettuna lapsuudessa tai nuoruudessa 1987-2008 eli 0-21-vuotiaana. Tieto kerättiin THL:n Lastensuojelurekisteristä. Kolme prosenttia ikäluokasta oli ollut sijoitettuna kodin ulkopuolelle. Kodin ulkopuolelle sijoitus jätettiin regressiomallien tarkastelusta pois, sillä näin tarkasteltuna muuttujaa ei voida määritellä omaksi tai vanhempiin liittyväksi tekijäksi. Kodin ulkopuolelle sijoitusta haluttiin kuitenkin tarkastella itsenäisenä syrjäytymiseen liittyvänä tekijänä.

Vanhemmilla vain perusasteen koulutus -tieto kertoo, oliko lapsen biologisten vanhempien korkein koulutus enintään perusasteen koulutus vuonna 2009, jolloin lapsi oli 21-vuotias. Tieto kerättiin Tilastokeskuksen koulutusrekisteristä. Vanhempien kouluttamattomuus koski 7 prosenttia ikäluokasta.
Vanhemmilla toimeentulotuen saantia -tieto kertoo, oliko lapsen biologinen vanhempi tai vanhemmat saaneet toimeentulotukea vuosina 1987-2008, jolloin lapsi oli 0-21-vuotias. Tieto kerättiin THL:n Toimeentulotukirekisteristä. Vanhempien toimeentulotuen saanti kosketti 38 prosenttia ikäluokasta.

Vanhemmilla psykiatrinen sairaus -tieto kertoo, oliko lapsen biologinen vanhempi saanut julkisesta erikoissairaanhoidosta psykiatrisen diagnoosin ICD-9 (290-319), ICD-10 (F00-99) vuosina 1987-2008, jolloin lapsi 0-21-vuotias. Tieto kerättiin THL:n Hoitoilmoitusrekisteristä. Vanhemman psykiatrinen sairastavuus koski 17 prosenttia ikäluokasta.

Lisäksi tarkasteltiin edellä mainittujen koulutuksen ja pitkittyneen työttömyyden mukaisesti jaettujen ryhmien välisiä eroja sosiaali- ja terveyspalveluiden käytössä ja ajoittumisessa selvittämällä eri ryhmien keskimääräinen kaikkien erikoisalojen poliklinikkakäyntien määrä vuosina 1998-2012 (7-25-vuotiaana), osastokäyntien määrä vuosina 1987-2012 (0-25-vuotiaana), psykiatrisen erikoisalan poliklinikkakäyntien määrä vuosina 1998-2012 (7-25-vuotiaana) sekä psykiatrisen erikoisalan osastokäyntien määrä vuosina 1987-2012 (0-25-vuotiaana). Tiedot saatiin THL:n Hoitoilmoitusrekisteristä. Syrjäytyneiden osalta tarkasteltiin myös, oliko lastensuojelun toimenpiteenä tehty kodin ulkopuolelle sijoitus ollut tahdonvastainen tai kiireellinen.

Sosiaali- ja terveyspalvelujen ajoittumista eri ryhmissä tarkasteltiin psykiatristen poliklinikka- ja osastokäyntien, päihdeperusteisten poliklinikka- ja osastokäyntien sekä lastensuojelun toimenpiteenä tehdyn kodin ulkopuolelle sijoittamisen keskimääräisen ensimmäisen ajankohdan mukaan, siten että laskettiin ryhmään kuuluvien keskimääräinen ikä ensimmäisen tapahtuman ajoittumishetkellä.

Tutkimuksen tilastolliset mallit tehtiin käyttäen logistista regressiota ja SPSS-tilasto-ohjelmaa. Syrjäytymiseen liittyvien tekijöiden sukupuolten välisten erojen tilastolliset merkitsevyydet testattiin $\chi^{2}$-testillä. Sukupuolen vaikutusta syrjäytymiseen selvitettiin sukupuolittain tehdyillä regressioanalyyseillä sekä käyttämällä interaktiotermejä. Palveluiden käytön määrien tai ajoittumisen eroja ryhmien välillä tutkittiin varianssianalyysillä. 


\section{TULOKSET}

Kaikkiaan 2186 (3,7 \%) vuonna 1987 Suomessa syntynyttä nuorta aikuista voitiin katsoa kuuluvan syrjäytyneiden ryhmään 25-28 -vuotiaana (Taulukko 1). Nuoria miehiä oli tilanteessa merkitsevästi nuoria naisia enemmän. Syrjäytyneitä miehiä oli yhteensä 1371 (4,6\%) ja naisia 815 $(2,9 \%)$. Koulutettujen työllisten ryhmä oli suurin, 77 prosenttia, koulutettuihin työttömiin sekä kouluttamattomiin työllisiin lukeutui joka kymmenes. Koulutettujen työllisten ryhmässä kaikkia tarkasteltuja taustatekijöitä esiintyi suhteellisen vähän, useimmiten omaa tai vanhempien saamaa toimeentulotukea tai psykiatrista sairastavuutta (Taulukko 1). Koulutetuilla työttömillä tutkitut taustatekijät olivat huomattavasti yleisempiä, edelleen oma tai vanhempien toimeentulotuen saanti ja psykiatrinen sairastavuus olivat yleisimmät. Rikostuomion oli saanut joka kuudes tähän ryhmään kuuluva. Koulutetuilla työttömillä taustatekijöitä esiintyi kuitenkin vähemmän kuin kouluttamattomilla työllisillä, joista kolmasosalla oli psykiatrinen diagnoosi ja useammalla kuin joka neljännellä rikostuomio. Ainoastaan toimeentulon vaikeudet toimeentulotuen käytöllä mitattuna olivat koulutetuilla työttömillä kouluttamattomia työllisiä hieman yleisempiä.

Syrjäytyneillä nuorilla aikuisilla kaikki tutkitut tekijät olivat muita ryhmiä huomattavasti yleisempiä. Syrjäytyneistä yhdeksän kymmenestä oli saanut edeltävästi toimeentulotukea, koulutetuista työllisistä ainoastaan viidesosa. Naiset olivat saaneet molemmissa ryhmissä toimeentulotukea merkitsevästi miehiä yleisemmin. Pitkäaikainen toimeentulotuen saanti oli syrjäytyneiden ryhmässä yleistä $(28,5 \%)$, kun taas koulutettujen työllisten ryhmässä se oli erittäin harvinaista. Psykiatrista sairastavuutta lapsuudessa ja nuoruudessa oli lähes puolella syrjäytyneistä, hieman useammin syrjäytyneillä naisilla kuin miehillä. Yksittäisistä psykiatrisista diagnooseista huomattavin ero koulutettujen työllisten ja syrjäytyneiden välillä nähtiin päihdediagnooseissa. Syrjäytyneistä lähes joka viidennellä oli nuoruudessa erikoissairaanhoidosta asetettu päihteisiin liittyvä diagnoosi, koulutetuista työllisistä ainoastaan vajaalla kahdella prosentilla. Syrjäytyneillä miehillä edeltävä päihdediagnoosi oli yleisempi kuin vastaavassa tilanteessa olevilla naisilla.
Syrjäytyneistä puolella oli edeltävästi tuomio rikoksista, kun koulutetuilla työllisillä prosenttiosuus oli 7. Miehillä rikostuomiot olivat huomattavasti naisia yleisempiä kaikissa ryhmissä. Viidesosalla (19\%) syrjäytymistä edelsi lapsena tai nuorena koettu lastensuojelun sijoitus kodin ulkopuolelle, naisilla miehiä useammin. Huomattavaa oli, että kaikista ikäluokan kiireellisesti sijoitetuista 303:sta puolet $(49 \%, 147)$ kuului syrjäytyneiden ryhmään. Samoin puolet ikäluokan tahdonvastaisesti kodin ulkopuolelle sijoitetuista 107:sta kuului syrjäytyneiden ryhmään (49\%, 52). Kaikki tarkastellut vanhempiin liittyvät tekijät olivat merkitsevästi yleisempiä syrjäytyneiden nuorten lapsuuden perheissä koulutettuihin työllisiin nähden. Syrjäytyneiden vanhemmilla lyhyt kouluttautuminen oli yli kolme kertaa yleisempää, köyhyys toimeentulotuen saannilla mitattuna yli kaksinkertaista ja psykiatrinen sairastavuuskin selvästi yleisempää.

Kaikki tarkastellut tekijät olivat yhteydessä syrjäytymiseen, ja regressioanalyysin mallissa 1 kaikki tarkastellut tekijät säilyivät edelleen tilastollisesti merkitsevinä (Taulukko 2). Yksittäisten tekijöiden vaikutus kuitenkin väheni. Edelleen toimeentulotuen saannin ja syrjäytymisen välinen yhteys oli voimakkain, sen jälkeen tulivat rikostuomio ja viimeisenä psykiatrinen sairastavuus. Miesten syrjäytymisen riski säilyi edelleen naisia suurempana. Vanhempiin liittyviä tekijöitä tarkasteltaessa (Malli 2) sekä lyhyen koulutuksen, toimeentulotuen saannin että psykiatrisen sairastavuuden yhteydet syrjäytymiseen säilyivät. Kun otettiin huomioon sekä omat että vanhempiin liittyvät tekijät (Malli 3), yksittäisten tekijöiden merkitys luonnollisesti pieneni entisestään. Vanhempiin liittyvistä tekijöistä merkitseviksi tekijöiksi jäivät vähäinen koulutus ja toimeentulotuen saanti. Nuoreen itseensä liittyvistä tekijöistä toimeentulotuen saannin ja syrjäytymisen yhteys säilyi edelleen voimakkaimpana. Merkitsevinä säilyivät myös rikostuomio sekä psykiatrinen sairastavuus. Kaikissa malleissa miessukupuolen yhteys syrjäytymiseen oli voimakkaampi. Kun analysoitiin samat mallit sukupuolittain, selvisi, että kaikkien mallien tilastollinen selitysaste (Nagelkerke R2) oli suurempi miehille. Kuitenkin sukupuoli-interaktiovaikutuksia tutkittaessa voitiin nähdä, että naissukupuoli yhdistettynä rikostaustaan oli merkitsevä, kuten myös mies- 


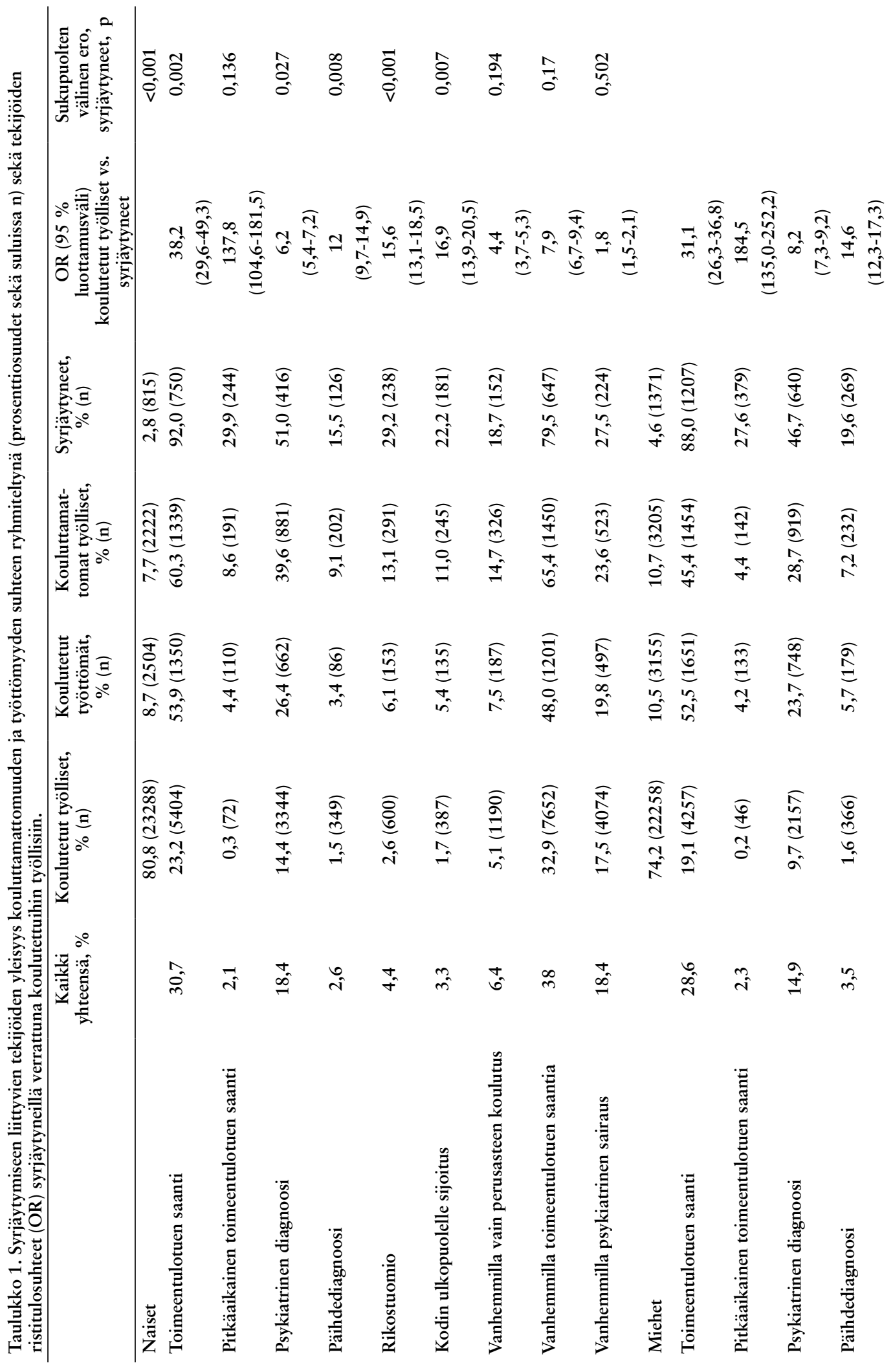




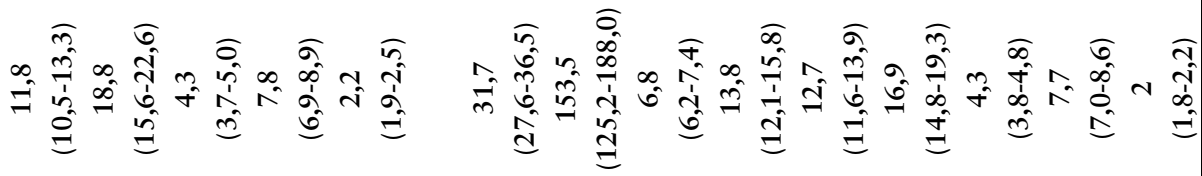

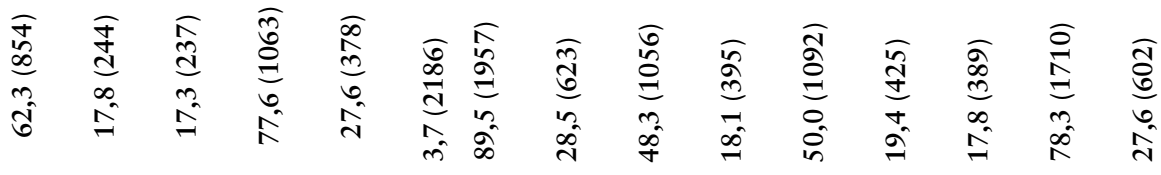

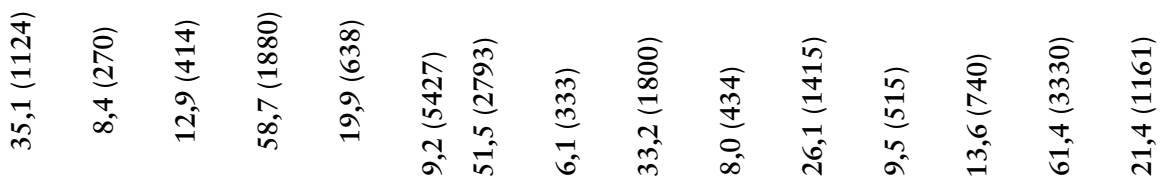

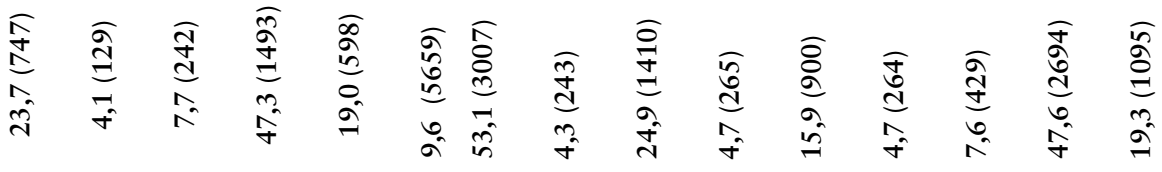

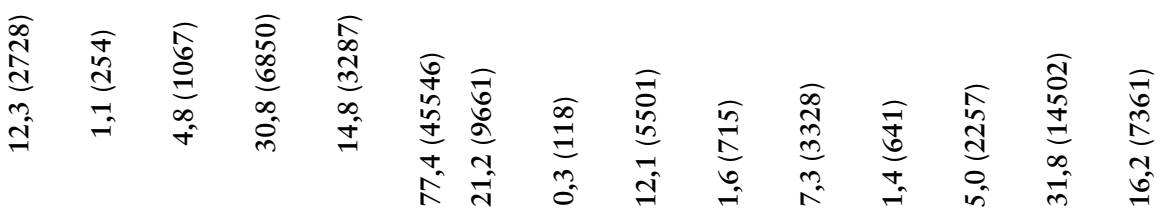

$\stackrel{2}{9} \rightarrow \stackrel{0}{0} \stackrel{0}{0}$

वें

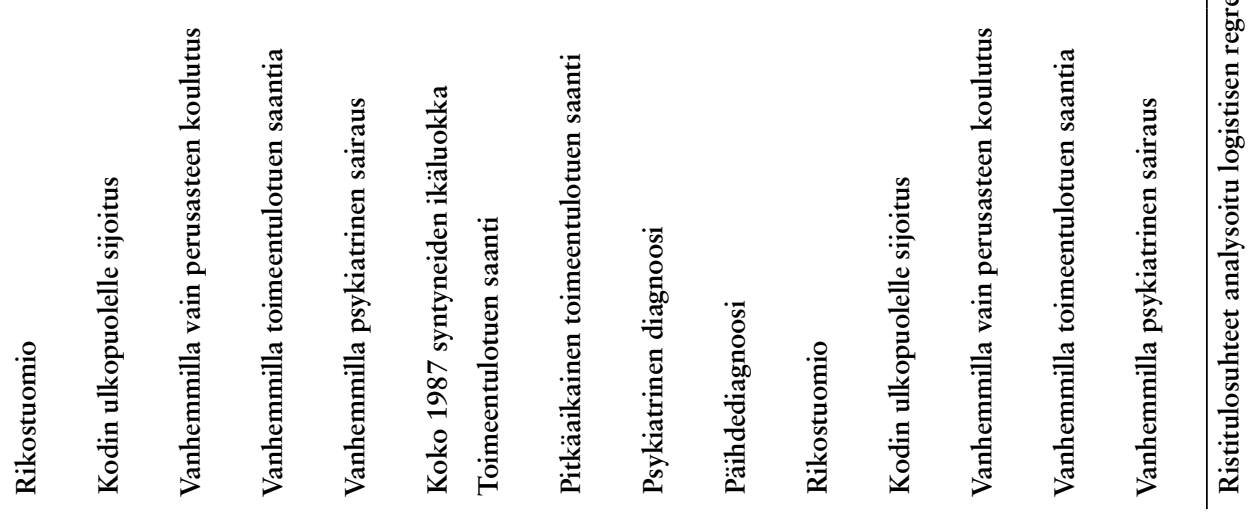


Taulukko 2. Syrjäytymiseen liittyvät tekijät, omien sekä vanhempien tekijöiden yhteistarkastelu. Vertailu tehty koulutettujen työllisten ja syrjäytyneiden välillä, vastemuuttujana on syrjäytyminen. Taulukossa on esitetty ristitulosuhteet (OR) ja tilastolliset merkitsevyydet (p-arvo).

\begin{tabular}{|c|c|c|c|c|c|c|}
\hline & \multicolumn{2}{|c|}{$\begin{array}{l}\text { Malli 1, } \\
\text { omat tekijät }\end{array}$} & \multicolumn{2}{|c|}{$\begin{array}{c}\text { Malli 2, } \\
\text { vanhempien tekijät }\end{array}$} & \multicolumn{2}{|c|}{$\begin{array}{c}\text { Malli 3, omat } \\
\text { sekä vanhempien tekijät }\end{array}$} \\
\hline & $\mathrm{p}$ & $\begin{array}{c}\text { OR (95\% } \\
\text { luottamusväli) }\end{array}$ & $\mathrm{p}$ & $\begin{array}{c}\text { OR (95\% } \\
\text { luottamusväli) }\end{array}$ & $\mathrm{p}$ & $\begin{array}{c}\text { OR (95\% } \\
\text { luottamusväli) }\end{array}$ \\
\hline Sukupuoli & $<0,001$ & $\begin{array}{c}1,5 \\
(1,3-1,6)\end{array}$ & $<0,001$ & $\begin{array}{c}1,9 \\
(1,7-2,1)\end{array}$ & $<0,001$ & $\begin{array}{c}1,5 \\
(1,4-1,7)\end{array}$ \\
\hline $\begin{array}{l}\text { Toimeentulotuen } \\
\text { saanti }\end{array}$ & $<0,001$ & $\begin{array}{c}20 \\
(17,4-23,1)\end{array}$ & & & $<0,001$ & $\begin{array}{c}14,1 \\
(12,2-16,4)\end{array}$ \\
\hline Rikostuomio & $<0,001$ & $\begin{array}{c}5,9 \\
(5,3-6,5)\end{array}$ & & & $<0,001$ & $\begin{array}{c}5,2 \\
(4,7-5,8)\end{array}$ \\
\hline $\begin{array}{l}\text { Psykiatrinen } \\
\text { diagnoosi }\end{array}$ & $<0,001$ & $\begin{array}{c}3,1 \\
(2,8-3,4)\end{array}$ & & & $<0,001$ & $\begin{array}{c}3,1 \\
(2,8-3,5)\end{array}$ \\
\hline $\begin{array}{l}\text { Vanhemmilla } \\
\text { vain perusasteen } \\
\text { koulutus }\end{array}$ & & & $<0,001$ & $\begin{array}{c}2,9 \\
(2,5-3,2)\end{array}$ & $<0,001$ & $\begin{array}{c}2,2 \\
(1,9-2,5)\end{array}$ \\
\hline $\begin{array}{l}\text { Vanhemmilla } \\
\text { toimeentulotuen } \\
\text { saantia }\end{array}$ & & & $<0,001$ & $\begin{array}{c}6,8 \\
(6,1-7,6)\end{array}$ & $<0,001$ & $\begin{array}{c}2,4 \\
(2,1-2,7)\end{array}$ \\
\hline $\begin{array}{l}\text { Vanhemmilla } \\
\text { psykiatrinen } \\
\text { diagnoosi }\end{array}$ & & & $<0,001$ & $\begin{array}{c}1,3 \\
(1,2-1,4)\end{array}$ & 0,209 & $\begin{array}{c}0,9 \\
(0,8-1,0)\end{array}$ \\
\hline
\end{tabular}

Ristitulosuhteet analysoitu logistisen regression avulla ja sukupuolten väliset erot $\chi^{2}$-testillä.

Taulukko 3. Erikoissairaanhoidon poliklinikka- ja osastokäyntien sekä psykiatristen poliklinikka- ja osastokäyntien keskimääräinen määrä koulutettujen työllisten ja syrjäytyneiden ryhmissä.

\begin{tabular}{|c|c|c|c|c|}
\hline & $\begin{array}{c}\text { Erikoissairaan- } \\
\text { boidon } \\
\text { poliklinikka- } \\
\text { käyntien mä̈̈rä } \\
\text { 1998-2012 }\end{array}$ & $\begin{array}{l}\text { Erikoissairaan- } \\
\text { boidon } \\
\text { osastokäyntien } \\
\text { määrä 1987-2012 }\end{array}$ & $\begin{array}{c}\text { Psykiatristen } \\
\text { poliklinikka- } \\
\text { käyntien määrä } \\
\text { 1998-2012 }\end{array}$ & $\begin{array}{c}\text { Psykiatristen } \\
\text { osastohoito- } \\
\text { jaksojen määra } \\
\text { 1987-2012 }\end{array}$ \\
\hline Koulutetut työlliset & 14 & 3 & 30 & 2,4 \\
\hline Syrjäytyneet & 31 & 5 & 30 & 2,6 \\
\hline$p$ & $<0,001$ & $<0,001$ & 0,868 & 0,042 \\
\hline \multicolumn{5}{|l|}{ Naiset } \\
\hline Koulutetut työlliset & 17 & 3,2 & 33 & 2,4 \\
\hline Syrjäytyneet & 42 & 5,7 & 39 & 2,6 \\
\hline$p$ & $<0,001$ & $<0,001$ & 0,032 & 0,347 \\
\hline \multicolumn{5}{|l|}{ Miehet } \\
\hline Koulutetut työlliset & 11 & 3,1 & 24 & 2,3 \\
\hline Syrjäytyneet & 24 & 4,4 & 24 & 2,7 \\
\hline$p$ & $<0,001$ & $<0,001$ & 0,912 & 0,044 \\
\hline
\end{tabular}

Yksisuuntaisen varianssianalyysin p-arvot 
Taulukko 4. Sosiaali- ja terveyspalvelujärjestelmään liittyvien ensimmäisten tapahtumien ajoittuminen koulutettujen työllisten ja syrjäytyneiden ryhmissä. Ryhmään kuuluvien keskimääräinen ikä tapahtumahetkellä.

\begin{tabular}{|c|c|c|c|c|c|}
\hline & $\begin{array}{c}\text { Sijoitus kodin } \\
\text { ulkopuolelle, } \\
\text { ikä }\end{array}$ & $\begin{array}{c}\text { Psykiatrinen } \\
\text { diagnoosi } \\
\text { poliklinikalla } \\
\text { 1998-2012, } \\
\text { ikä }\end{array}$ & $\begin{array}{c}\text { Psykiatrinen } \\
\text { diagnoosi } \\
\text { osastolla } \\
\text { 1987-2012, } \\
\text { ikä }\end{array}$ & $\begin{array}{c}\text { Päihde- } \\
\text { perusteinen } \\
\text { hoito } \\
\text { poliklinikalla } \\
\text { 1998-2012, } \\
\text { ikä }\end{array}$ & $\begin{array}{c}\text { Päibde- } \\
\text { perusteinen } \\
\text { boito } \\
\text { osastolla } \\
\text { 1987-2012, } \\
\text { ikä }\end{array}$ \\
\hline Koulutetut työlliset & 9,7 & 18 & 15,2 & 20,3 & 19,6 \\
\hline Syrjäytyneet & 11,8 & 17,5 & 16,1 & 21,1 & 20,7 \\
\hline$p$ & $<0,001$ & 0,001 & 0,007 & 0,001 & $<0,001$ \\
\hline \multicolumn{6}{|l|}{ Naiset } \\
\hline Koulutetut työlliset & 10,4 & 18,3 & 16,4 & 19,9 & 19,1 \\
\hline Syrjäytyneet & 11,7 & 17,7 & 16,8 & 20,9 & 20,6 \\
\hline$p$ & 0,004 & 0,003 & 0,345 & 0,008 & 0,002 \\
\hline \multicolumn{6}{|l|}{ Miehet } \\
\hline Koulutetut työlliset & 8,7 & 17,4 & 13,7 & 20,7 & 20,1 \\
\hline Syrjäytyneet & 11,8 & 17,3 & 15,6 & 21,2 & 20,7 \\
\hline$p$ & $<0,001$ & 0,742 & $<0,001$ & 0,114 & 0,087 \\
\hline
\end{tabular}

Yksisuuntaisen varianssianalyysin p-arvot

sukupuoli yhdistettynä omaan sekä vanhempien psykiatriseen sairastavuuteen.

Erikoissairaanhoidon kaikkien erikoisalojen poliklinikkakäyntejä oli syrjäytyneillä keskimäärin yli kaksinkertainen määrä verrattaessa koulutettuihin työllisiin, Taulukko 3. Myös erikoissairaanhoidon osastokäyntejä syrjäytyneille oli kertynyt koulutettuja työllisiä enemmän. Myös psykiatrisia osastokäyntejä syrjäytyneillä oli hieman koulutettuja työllisiä enemmän. Sen sijaan vain syrjäytyneillä naisilla psykiatrisia poliklinikkakäyntejä oli koulutettuja työllisiä enemmän.

Syrjäytyneiden ryhmän palvelujärjestelmän kohtaaminen ajoittui eri tavoin kuin koulutettujen työllisten, Taulukko 4. Kodin ulkopuolelle sijoitetut syrjäytyneet oli sijoitettu keskimäärin 11,8-vuotiaina, koulutetut työlliset kaksi vuotta aiemmin, 9,7-vuotiaina. Miehillä ero ryhmien välillä oli yli kolme vuotta, naisillakin reilu vuosi. Psykiatrisen erikoissairaanhoidon ensimmäinen poliklinikkakäynti ajoittui syrjäytyneillä keskimäärin 17,5 vuoden ja koulutettujen työllisten 18 vuoden ikään. Naisilla ryhmien välinen ero oli tilastollisesti merkitsevä. Sen sijaan psykiatristen osastokäyntien ajoittumisen osalta tilanne oli päinvastoin. Syrjäytyneillä ensimmäinen osastokäynti ajoittui keskimäärin 16,1 vuoden ikään, koulutetuilla työllisillä 15,2 vuoden ikään, syrjäytyneillä miehillä ensimmäinen käynti oli keskimäärin kaksi vuotta koulutettuja työllisiä myöhemmin. Myös päihdeperusteiseen erikoissairaanhoitoon syrjäytyneet olivat tulleet noin vuosi koulutettuja työllisiä myöhemmin, mikä ero oli myös tilastollisesti merkitsevä.

\section{JOHTOPÄÄTÖKSET JA POHDINTA}

Aiemmissa sekä vuonna 1977 että 1987 syntyneiden ikäluokan tutkimuksissa on todettu, että noin neljällä prosentilla nuorista ongelmat kasautuvat $(28,29)$. Samansuuruinen joukko, 3,7 prosenttia vuonna 1987 syntyneistä laskettiin tässä tutkimuksessa kuuluvaksi syrjäytyneiden ryhmään. He olivat vailla toisen asteen jatkotutkintoa 25 -vuotiaina ja neljän vuoden aikana 25-28 vuoden iässä yhteensä 300 päivää tai enemmän työttömänä. Ryhmään kuului selkeästi enemmän miehiä kuin naisia.

Nuorten aikuisten syrjäytymisen voidaan katsoa olevan lapsuuden ja nuoruuden ongelmien jatkumo. Syrjäytyneiden joukolla nähtiin lukuisia ongelmia lapsuudessa ja nuoruudessa, kun taas koulutetuilla, jotka eivät kärsineet pitkittyneestä työttömyydestä, muita ongelmia nähtiin vain vähän. Näiden ääripäiden väliin 
jäivät koulutetut, mutta pitkittyneesti työttömät, joilla ongelmia oli jonkin verran, sekä kouluttamattomat, jotka eivät kärsineet pitkittyneestä työttömyydestä. Heillä ongelmia oli koulutettuja useammin. Ainoastaan toimeentulon vaikeudet olivat koulutetuilla työttömillä kouluttamattomia työllisiä yleisempiä. Näyttää siis siltä, että koulutus ja työelämään kiinnittyminen kietoutuvat voimakkaasti toisiinsa ja myös aiemman elämän ongelmat ovat näihin voimistuen yhteydessä. Kouluttamattomuus on jopa pitkäaikaista työttömyyttä vahvemmin yhteydessä muihin ongelmiin. Suurimmat ja tämän tutkimuksen tuloksissa esitetyt erot löytyivät luonnollisesti syrjäytyneiden ja koulutettujen työllisten väliltä, mutta syrjäytyneiden ryhmällä ongelmat olivat merkitsevästi yleisempiä myös koko muuhun ikäluokkaan sekä tutkimuksen muihin ryhmiin nähden.

Aiemmin syrjäytymisen keskeisiksi taustatekijöiksi on todettu mielenterveys- ja päihdeongelmat sekä oppimisvaikeudet ja työttömyys (8). Myös tässä tutkimuksessa mielenterveys- ja päihdeongelmat sekä lisäksi rikollisuus ja toimeentulon vaikeudet liittyivät syrjäytymiseen. Erityisesti pitkäaikainen viimesijaiseen toimeentuloturvaan turvautuminen oli voimakkaasti yhteydessä syrjäytymiseen. Tämän valossa huolestuttava tieto on, että vain joka neljäs pitkäaikaisesti ja pääasiallisesti viimesijaisen turvan piirissä olevista palaa työelämään tai ensisijaisten etuuksien piiriin (30). Toimeentulo-ongelmien jälkeen voimakkaimmin syrjäytymiseen yhdistyivät kodin ulkopuolelle sijoitus, päihdeongelma, rikostuomio sekä vanhempien köyhyys toimeentulotuen saannilla mitattuna.

Tulokset vahvistavat, että nuoret miehet ovat nuoria naisia suuremmassa syrjäytymisvaarassa (14). Tulosta voi osaltaan selittää aiempi havainto nuorten miesten alhaisen koulutustason vahvemmasta yhteydestä työttömyyteen (31). Sekä naisilla että miehillä kaikki tarkastellut muuttujat yhdistyivät syrjäytymiseen, mutta tilastollisten mallien selitysaste oli suurempi miehille. Interaktiomallien perusteella rikostausta kuitenkin lisäsi enemmän naisten syrjäytymisen todennäköisyyttä, omat ja vanhempien mielenterveysongelmat taas olivat selkeämmin yhteydessä miesten syrjäytymiseen. Tulokset antavat siis myös viitteitä siitä, että lapsuuden perheen vaikeudet voivat vaikuttaa voimakkaammin poikiin. Aiempien tutkimusten perusteella tiedetään, että lap- sen sukupuoli vaikuttaa niihin mekanismeihin, miten vanhempien vaikeudet vaikuttavat lasten myöhempään kehitykseen (32). Sukupuolella on merkitystä myös vanhemmuuden ja sosiaalisten suhteiden keskinäisiin yhteyksiin (33). Tutkimuksia aiheesta on vähän, mutta yleisesti ajatellaan, että perheen vaikutus on merkittävämpi poikien sosiaalisten suhteiden muodostumiselle (33). Joka tapauksessa näiden tulosten valossa erityisen huomion kohteena pitäisi olla poikien hyvinvoinnin vahvistaminen ja koulunkäynnin tukeminen, etenkin jos perheissä tai lapsilla itsellään on mielenterveyden ongelmia.

Hyvinvointiongelmien ylisukupolvisuus eli vanhempien ongelmien siirtyminen heidän lastensa ongelmiksi tulee vahvistettua myös tässä tutkimuksessa. Kaikki tarkastellut vanhempien vaikeudet lisäsivät heidän lastensa syrjäytymisen todennäköisyyttä. Merkittävimmin syrjäytymiseen yhdistyi vanhempien toimeentulotuen saanti. Vauhkosen ja kumppaneiden (12) mukaan toimeentulotuen ylisukupolvinen asiakkuus kertoo vanhempien kasautuneesta huono-osaisuudesta, ei pelkästä tuloköyhyydestä. Vanhempien kasautuneella huono-osaisuudella on voimakkaimmat ylisukupolviset vaikutukset, eikä kyse ole ainoastaan materiaalisesta siirtymisestä vanhemmilta lapsille, vaan myös kulttuurisista ja muista kuin taloudellisista tekijöistä (12). Erityisesti kasautuneen huono-osaisuuden tuhoisia vaikutuksia olisi pyrittävä ehkäisemään varhaisessa vaiheessa.

Tulokset antavat myös viitteitä siitä, että sosiaali- ja terveyspalvelujärjestelmä liittyy syrjäytymiseen. Tarkasteltujen sosiaali- ja terveyspalvelujärjestelmän käyttötietojen perusteella voidaan sanoa, että palveluiden käyttö lapsuudessa ja nuoruudessa on yleisempää niillä, jotka jäävät myöhemmässä vaiheessa koulutuksen ja työelämän ulkopuolelle. Syrjäytyneillä kohtaamisia palvelujärjestelmän kanssa oli ollut merkitsevästi koulutettuja työllisiä enemmän. Tulos vahvistaa aiempia tutkimuksia syrjäytymistä edeltävistä lapsuuteen liittyvistä sosiaalisista ja terveydellisistä ongelmista ja suuremmasta palveluiden käytöstä (24). Huomionarvoista on, että vaikka syrjäytyneillä kaikkien erikoisalojen poliklinikka- ja osastokäyntejä olikin koulutettuja työllisiä huomattavasti enemmän, psykiatristen poliklinikkakäyntien määrässä ei nähty eroa syrjäytyneiden ja koulutettujen työllisten miesten välillä. Syrjäytyneillä naisilla myös psykiatrisia 
poliklinikkakäyntejä oli koulutettuja työllisiä enemmän. Tämän sekä muiden ongelmien perusteella olisi voinut olettaa, että myös syrjäytyneillä miehillä psykiatrisia poliklinikkakäyntejä olisi ollut koulutettuja työllisiä enemmän. Toisaalta voidaan ajatella, että vakavat ongelmat on hoidettu psykiatrisessa osastohoidossa, joita jaksoja syrjäytyneillä olikin hieman koulutettuja työllisiä enemmän. Syrjäytyneet tulivat myös psykiatriseen osastohoitoon sekä päihdehoitoon koulutettuja työllisiä myöhemmin, huolimatta varhaisemmasta psykiatrisesta diagnoosista. Syrjäytyneiden nuorten miesten ensimmäinen psykiatrinen osastohoito ajoittui lähes kaksi vuotta koulutettuja työllisiä myöhempään. Tulosten perusteella voidaan ajatella, että erityisesti syrjäytyneillä miehillä on psykiatristen palvelujen alikäyttöä. Voidaan myös pohtia, olisiko syrjäytyneiden ryhmässä vieläkin suurempi tarve psykiatriselle hoidolle, ja ovatko psykiatriset ongelmat lisänneet myös muiden erikoisalojen käyntimääriä. Nämä tulokset yhdistettynä tietoon mielenterveysongelmissa painivien nuorten miesten terveydenhuollon palveluiden alikäytöstä (25), mielenterveys- ja päihdepalveluiden aukoista (34), palveluiden epätasaisesta saatavuudesta (26) sekä tietoon siitä, että nykyisin nuoren tarvitseman tuen laajuus saatetaan tunnistaa vasta sitten, kun tilanne on muodostua erityisen vaikeaksi (35), olisi kuitenkin syytä ottaa vakavasti.

Myös lastensuojelun toimet herättävät kysymyksiä. Syrjäytyneiden kohdalla kodin ulkopuolelle sijoittaminen oli tapahtunut keskimäärin noin kaksi vuotta myöhemmin, pojilla jopa kolme vuotta myöhemmin kuin saman kokeneilla koulutetuilla työllisillä ikätovereilla. Syrjäytyneiden sijoitukset olivat lisäksi olleet hyvin usein kiireellisiä ja tahdonvastaisia. Tiedetään, että kodin ulkopuolelle sijoittamisen syyt vaihtelevat iän mukaan, siten, että nuorempien sijoitukset liittyvät useammin vanhempien ongelmiin, teini-iän sijoitukset taas omiin vaikeuksiin (36). Tässä tutkimuksessa kuitenkin syrjäytyneillä sekä perheen että omia ongelmia oli ollut huomattavan paljon, ja perheissä monenlaista tuen tarvetta. Aiempien tutkimusten perusteella tiedetään, että pisimmälle opiskelevat alle 13-vuotiaana perheisiin sijoitetut tytöt ja pojat, ja parhaiten yhteiskuntaan kiinnittyvät ne naiset, jotka on lapsena sijoitettu perhehoitoon (37). Myöhemmin heikoimmassa tilanteessa taas ovat laitoshoidossa ja mones- sa sijoituspaikassa olleet pojat (37). Tämänkin vuoksi lastensuojelun tukitoimien oikea-aikaisuus ja tarpeenmukaisuus on olennaisen tärkeää. Selvitysten perusteella tiedetään, että kodin ulkopuolelle sijoitettujen lasten perheissä on huomattavan usein köyhyyttä ja mielenterveys- ja päihdeongelmia $(36,38)$, mutta suuri osa päihde- ja mielenterveyspalveluita tarvitsevista lapsista ja vanhemmista jää silti ilman näitä palveluita (36).

Tämän tutkimuksen tulosten valossa näyttää siis siltä, että syrjäytymisen syynä ovat paitsi mielenterveys- ja päihdeongelmat, keskeisenä tekijänä on myös niihin saadun avun riittämättömyys tai avun saaminen liian myöhään.

Tämän vuoksi sosiaali- ja terveyspalveluiden saatavuuteen ja toimivuuteen pitäisi kiinnittää erityistä huomiota erityisesti monenlaisen tuen tarpeessa olevien perheiden ja nuorten kohdalla, etteivät tilanteet ehtisi monimutkaistua. Jo aiemmin vastauksena nuorten syrjäytymiseen on ehdotettu yhden luukun palveluita, riittäviä työntekijäresursseja ja vastuutyöntekijämallia sekä erityissatsausta matalan kynnyksen mielenterveyspalveluihin (24). Näihin kannattaisi myös tämän tutkimuksen tulosten valossa satsata.

Tutkimuksen vahvuus on koko ikäluokan kattava aineisto, jonka tiedot perustuvat viranomaisrekistereihin. Aineisto ei siis ole painottunut esimerkiksi taustatekijöiden mukaan. Aineistosta löytyy kattavasti tietoa syrjäytymiseen liittyvistä taustatekijöistä sekä myös puolueetonta tietoa palvelujärjestelmään liittyen. Aineiston koko mahdollistaa sukupuolittaiset ja koulutuksen ja työllisyyden mukaan tarkemmat ryhmittelyt, eivätkä yksittäiset tapaukset vaikuta lopputuloksiin. Pitkittäisseuranta on ainoa tapa saada kattavasti tietoa eri ryhmien palvelujärjestelmäkohtaamisista. Tutkimuksen tulokset herättävät kuitenkin paljon kysymyksiä, joihin tämän tutkimuksen aineisto ei kykene tarjoamaan vastauksia. Huomataanko ongelmat tarpeeksi ajoissa? Annetaanko perheille tukea, joka mahdollistaa perheiden ja lasten hyvinvoinnin? Kyetäänkö lasten ja nuorten ongelmiin antamaan apua ehkäisevästi ja oikea-aikaisesti? Riittääkö annettu apu ja onko se tarpeeksi kokonaisvaltaista? Vai jäävätkö toimet yksittäisiksi pistemäisiksi tapaamisiksi, käynneiksi tai toimenpiteiksi? Esiintyykö näillä nuorilla niin paljon ongelmia, etteivät järjestelmä ja toimijat kykene heitä auttamaan? Vai eikö hyvää tarkoittava apu ja tuki autakaan, 
vaan käytännössä haittaa ja vaikeuttaa tilanteita entisestään? Vastauksia on etsittävä jatkossa yhteistyössä erilaisten laadullisten sekä tilastoaineistojen avulla.

Tässä tutkimuksessa on tarkasteltu tietääksemme tähän mennessä kattavimmin syrjäytymiseen liittyviä tekijöitä. Yksittäisiin tekijöihin keskittyminen on tärkeää, mutta se ei tuo esiin varsinaisen ongelman vakavuutta ja monitahoisuutta. Tämän tutkimuksen tulokset todistavat, että nuorten aikuisten pitkäaikaistyöttömyys ja kouluttamattomuus on ongelma, johon tarvitaan kokonaisvaltaisia ratkaisuja ja palvelujärjestelmän rakenteellisia muutoksia. Tulosten perusteella erityistä huomiota tulisi kiinnittää mielenterveyspalveluiden toimivuuteen ja saatavuuteen. Syrjäytymisellä on pitkät juuret ja moninaiset taustat, ja ylisukupolvisuus on nähtävissä tässäkin tutkimuksessa. Elämänkaarinäkökulman mukaan voidaan ajatella, että syrjäytyminen on aikuisuuden normaaleista kehitystehtävistä ulos jäämistä. Tämän tutkimuksen perusteella ulos jäämiseen on liittynyt monenlaisia tekijöitä ja mekanismeja, joiden vuoksi nämä nuoret aikuiset eivät ole saaneet aikuisuudelta vaadittavia taitoja. Ongelmat alkavat usein varhain, jolloin vanhempien ongelmat tuovat omat esteensä kas- vuun ja kehitykseen. Kouluun liittyvät vaikeudet tai mielenterveysongelmat vaikeuttavat jatkokoulutukseen hakeutumista ja oman elämän rakentamista. Yhteiskunnan tuki näyttäytyy tämän tutkimuksen valossa riittämättömältä ja paikoin jopa syrjäyttävältä. Koska syrjäytyminen ei ole pelkästään alhaisen koulutuksen tai työttömyyden seuraus, vaan myös kokemuksellisten tekijöiden kuten yksinäisyyden, epäluottamuksen ja alisuoriutumisen muodostama kierre (39), pitäisi yhteiskunnan tuen ja rakenteiden vastata erityisesti nuorten miesten pystyvyyden ja työllistymiseen liittyvien kykyjen vahvistamiseen. Tämä tarkoittaa sitä, että syrjäytymisen vähentämiseksi tarvitaan satsauksia ehkäisevään työhön ja perheiden tukeen sekä lisäksi nuorten tarpeista lähtevää kokonaisvaltaista palvelua.

\section{KIRJOITTAJIEN KONTRIBUUTIOT:}

Paananen on vastannut tutkimuksen analyysien tekemisestä sekä kirjoittanut tämän artikkelin. Surakka on auttanut tutkimusanalyysien tekemisessä sekä artikkelin kirjoittamisessa. Kainulainen on osallistunut tutkimustulosten tulkintaan sekä artikkelin kirjoittamiseen. Ristikari ja Gissler ovat vastanneet aineistosta sekä osallistuneet kirjoittamiseen.

Paananen, R., Surakka,A., Kainulainen, S., Ristikari,T., Gissler, M. Social exclusion in early adulthood, related factors and the timing of the social and health care services. Sosiaalilääketieteellinen aikakauslehti - Journal of Social Medicine 2019: 56: I 14-128.

In decision-making, understanding the big picture of social exclusion is still mostly lacking. This leads to dispersed and separate actions and solutions at various levels, which often complicate individuals' situations. Also, there is a large discrepancy between the young people's needs and the current services.

In this study, social exclusion is determined as lack of secondary level education at the age of 25 together with long-term unemployment at ages 25-28, which means deviation from the life course norms.

This study investigates the prevalence and sex differences of the social exclusion with The Finnish Birth Cohort 1987 register data. This study also investigates the related factors in childhood and adolescence, and whether the usage and tim- ing of the social and health care services differ between the groups of 'the educated employed' and 'the socially excluded'.

3.7 percent of the young people born in Finland in 1987 could be described as socially excluded, mostly men. Education was more tightly twined with other problems than the unemployment and numerous own and family-related problems could be determined in childhood and adolescence. The related factors showed some sex specificities. Interestingly, the usage and the timing of the social and health care services differed significantly between 'the educated employed' and 'the socially excluded'.

This study confirms the intertwining of the education and the employment, to which other well-being problems also interact. This study 
extends the knowledge on factors and sex specificities related to social exclusion, and provides further information on the role of the social and health care system in the process of social exclusion.
Keywords: Young people, Social and health care system, Well-being, NEET

$\begin{array}{cc}\text { Saapunut } & 25.06 .2018 \\ \text { Hyväksytty } & 27.11 .2018\end{array}$

\section{LÄHTEET}

(1) Albæk K, Asplund R, Barth E, ym. Youth unemployment and inactivity: A comparison of school-to-work transitions and labour market outcomes in four Nordic countries. TemaNord. Copenhagen: Nordic Council of Ministers; 2015.

(2) Larja L, Törmäkangas L, Merikukka M, ym. NEET-indikaattori kuvaa nuorten syrjäytymistä. Tieto \& Trendit 2016;2.

(3) Kerätär R. Kun katsoo kauempaa, näkee enemmän. Monialainen työkyvyn ja kuntoutustarpeen arviointi pitkäaikaistyöttömillä. Acta Universitatis Ouluensis D Medica 1340. Oulu: Oulun yliopisto; 2016.

(4) Nilsen Ø, Reiso K. Scarring effects of earlycareer unemployment. Kirjassa: Rosholm M, Svarer M. (toim.) Consequences of youth unemployment and effectiveness of policy interventions. Nordic Economic Policy Review. Copenhagen: Nordic Council of Ministers; 2014(1):13-46.

(5) Myrskylä P. Nuoret työmarkkinoiden ja opiskelun ulkopuolella. Työ- ja elinkeinoministeriön julkaisuja. Työ ja yrittäjyys 12/2011. Helsinki: Työ- ja elinkeinoministeriö; 2011.

(6) Alatalo J, Mähönen E, Räisänen H. Nuorten ja nuorten aikuisten työelämä ja sen ulkopuolisuus. Tem-analyysejä 76/2017. Helsinki: Työ- ja elinkeinoministeriö; 2017.

(7) Eurofound. Exploring the diversity of NEETs. Luxembourg: Publications Office of the European Union; 2016. doi: 10.2806/15992.

(8) Notkola V, Pitkänen S, Tuusa M, ym. Nuorten syrjäytyminen. Tietoa, toimintaa ja tuloksia? Eduskunnan tarkastusvaliokunnan julkaisu 1/2013. Helsinki: Eduskunta; 2013.

(9) Lämsä AL. Tuhat tarinaa lasten ja nuorten syrjäytymisestä. Lasten ja nuorten syrjäytyminen sosiaalihuollon asiakirjojen valossa. Acta Universitatis Ouluensis E 102 Scientiae Rerum Socialium Oulu: Oulun yliopisto; 2009.

(10) Paananen R, Ristikari T, Merikukka M, ym. Lasten ja nuorten hyvinvointi Kansallinen syntymäkohortti 1987 -tutkimusaineiston valossa, Raportti 52/2012. Helsinki: Terveyden ja hyvinvoinnin laitos; 2012.

(11) Junttila N. Social competence and loneliness during the school years - Issues in assessment, interrelations and intergenerational transmission. Annales Universitatis Turkuensis B 325. Turku: Turun yliopisto; 2010.
(12) Vauhkonen T, Kallio J, Kauppinen T, ym. Intergenerational accumulation of social disadvantages across generations in young adulthood. Research in social stratification and mobility 2017;48:42-52. doi:10.1016/j.rssm.2017.02.001

(13) Kestilä L, Väisänen A, Paananen R, ym. Kodin ulkopuolelle sijoitetut nuorina aikuisina.

Rekisteripohjainen seurantatutkimus Suomessa vuonna 1987 syntyneistä. Yhteiskuntapolitiikka 2012;77:6.

(14) Myrskylä P. Hukassa - Keitä ovat syrjäytyneet nuoret? EVA analyysi n:o 19, Helsinki: Elinkeinoelämän valtuuskunta; 2012.

(15) Scott I, Fowler D, McGorry P, ym. Adolescents and young adults who are not in employment, education, or training BMJ 2013;347:f5270. doi: $10.1136 / \mathrm{bmj} .55270$

(16) Rönkä AR. Experiences of loneliness from childhood to young adulthood. Study of the Northern Finland Birth Cohort 1986. Acta Univ. Oul. E 172. Oulu: Oulun Yliopisto; 2017, 148.

(17) Sourander A, Gyllenberg D, Brunstein K, ym. Association of Bullying Behavior at 8 Years of Age and Use of Specialized Services for Psychiatric Disorders by 29 Years of Age. JAMA Psychiatry 2016;73(2):159-165. doi:10.1001/jamapsychiatry.2015.2419

(18) Arnett JJ. Emerging adulthood. A theory of development from the late teens through the twenties. Am Psychol. 2000 May;55(5):469-80. doi:10.1037/0003-066X.55.5.469

(19) Dunderfelt T. Elämänkaaripsykologia: lapsen kasvusta yksilön henkiseen kehitykseen. Helsinki: WSOY; 1997.

(20) Nurmi J, Ahonen T, Lyytinen H ym. Ihmisen psykologinen kehitys. Porvoo: WSOY; 2006.

(21) Anttila R, Eronen S, Kallio M, ym. Persoona 2 - Kehityspsykologia, oppikirja. Helsinki: Edita Prima Oy; 2010.

(22) Sen A. Inequality reexamined. Harvard University Press; 1992.

(23) Bynner J. Risks and outcomes of social exclusion. Insights from longitudinal data. OECD, Paris, mimeo; 1999.

(24) Aaltonen S, Berg P, Ikäheimo S. Nuoret luukulla. Kolme näkökulmaa syrjäytymiseen ja nuorten asemaan palvelujärjestelmässä. Verkkojulkaisuja 84. Helsinki: Nuorisotutkimusverkosto/ Nuorisotutkimusseura; 2015.

(25) Vanheusden K, van der Ende J, Mulder CL $\mathrm{ym}$. The use of mental health services among 
young adults with emotional and behavioural problems: equal use for equal needs? Soc Psychiatry Psychiatr Epidemiol 2008;43:808-15. doi:10.1007/s00127-008-0367-4

(26) Paananen R, Santalahti P, Merikukka M ym. Socioeconomic and regional aspects in the use of specialized psychiatric care-a Finnish nationwide follow-up study. Eur. J. Public Health 2013;23:372-377.

doi:10.1093/eurpub/cks147

(27) Paananen R, Gissler M. Cohort Profile: The 1987 Finnish Birth Cohort. Int J Epidemiol 2011;41:4:941-945. doi:10.1093/ije/dyr035

(28) Ilmakunnas I, Kauppinen T, Kestilä L. Sosioekonomisten syrjäytymisriskien kasautuminen vuonna 1977 syntyneillä nuorilla aikuisilla. Yhteiskuntapolitiikka 2015;80:3:247-262.

(29) Sutela E, Törmäkangas L, Toikka E, ym. Nuorten hyvinvointi ja syrjäytymisen riskitekijät Suomen kuudessa suurimmassa kaupungissa Helsinki, Espoo, Vantaa, Turku, Tampere ja Oulu. Raportti 5/2016. Helsinki: Terveyden ja hyvinvoinnin laitos; 2016.

(30) Surakka, A, Pyykkönen T, Myrskylä P, ym. Kerran asiakas, aina asiakas? - Viimesijaisen turvan pitkäaikaisasiakkuus 2000-luvun Suomessa. Kirjassa Saari J. (toim.) Sosiaaliturvariippuvuus - Sosiaalipummit oleskeluyhteiskunnassa? Tampere; 2017.

(31) Sipilä N, Kestilä L, Martikainen P. Koulutuksen yhteys nuorten työttömyyteen. Mihin peruskoulututkinto riittää 2000-luvun alussa? Yhteiskuntapolitiikka 2011;76:2.

(32) Vallotton CD, Harewood T, Ayoub CA, ym. Buffering boys and boosting girls: The protective and promotive effects of Early Head Start for children's expressive language in the context of parenting stress Early Child Res Q 2012;27:696-707. doi: 10.1016/j.ecresq.2011.03.001

(33) Neitola M. Lapsen sosiaalisen kompetenssin tukeminen - vanhempien epäsuorat ja suorat vaikutustavat C:324. Turku: Turun Yliopisto; 2011.

(34) Peltola M, Moisio J. Ääniä ja äänettömyyttä palvelukentillä - katsaus lasten ja nuorten palvelukokemuksia koskevaan tietoon. Nuorisotutkimusverkosto/ Nuorisotutkimusseura Verkkojulkaisuja 112. Helsinki: 2017.
(35) Määttä A, Keskitalo E. Ulkoringiltä sisärinkiin. Kumuloituneista ongelmista kärsivät nuoret aikuiset pirstaleisessa palvelujärjestelmässä. Yhteiskuntapolitiikka 2014;79:2.

(36) Heino T, Hyry S, Ikäheimo S, ym. Lasten kodin ulkopuolelle sijoittamisen syyt, taustat, palvelut ja kustannukset HuosTa-hankkeen (2014-2015) päätulokset. Terveyden ja hyvinvoinnin laitoksen raportteja 3/2016. Tampere: Juvenes Print - Suomen Yliopistopaino Oy; 2016.

(37) Heino T, Johnson M. Huostassa olleet lapset nuorina aikuisina. Kirjassa Hämäläinen U, Kangas O (toim.) Perhepiirissä. Helsinki: Kela; 2010.

(38) Saarikallio-Torp M, Heino T, Hiilamo H, ym. Lapset huostassa, vanhemmat ahdingossa. Kirjassa Hämäläinen U, Kangas O. (toim.) Perhepiirissä. Helsinki: Kela; 2010.

(39) Lehtonen O, Kallunki V. Nuorten aikuisten syrjäytymiskierre. Janus Sosiaalipolitiikan ja sosiaalityön tutkimuksen aikakauslehti 2013;21:2.

\section{Reija PaAnanen}

FT, dosentti

Diakonia-ammattikorkeakoulu

Anne SurakKa

TtM, VTM

Diakonia-ammattikorkeakoulu

SAKari KaInUlainen

YTT, dosentti

Diakonia-ammattikorkeakoulu

TIINA RISTIKARI

YTT, tutkimuspäällikkö

Terveyden ja byvinvoinnin laitos

Lapset, nuoret ja perheet

\section{Mika GISSLER}

FT, tutkimusprofessori

Terveyden ja hyvinvoinnin laitos

Tietopalvelut

Turun yliopisto

Lastenpsykiatrian tutkimuskeskus 